\title{
Effects of effluent and urea application on groundwater, soil and pastures at WTARS
}

\author{
C.G. ROACH ${ }^{1}$, G. STEVENS ${ }^{2}$, D.A. CLARK ${ }^{3}$ and P. NICHOLAS ${ }^{3}$ \\ ${ }^{1}$ WestpacTrust Agricultural Research Station, R.D.13, Hawera \\ ${ }^{2}$ Taranaki Regional Council, Private Bag 713, Stratford \\ ${ }^{3}$ Dairying Research Corporation, Private Bag 3123, Hamilton \\ drchaw@netsource.co.nz
}

\begin{abstract}
Land application of dairy effluent is being encouraged by many regional councils, and the use of urea fertiliser on dairy farms has increased over recent years. A 3-year trial was started in September 1997 to investigate the effects of urea and dairy effluent applications on pastures, soils and groundwater quality. Twenty-one 0.25 ha paddocks received urea or dairy effluent at rates of $0,100,200$, or $400 \mathrm{~kg} \mathrm{~N} / \mathrm{ha} / \mathrm{yr}$, and were grazed by dairy cows. Increasing nitrogen application rates resulted in increased pasture production and ryegrass content, and nitrate leaching to ground water. Nitrate leaching was estimated to be 14,18 , 26 and $56 \mathrm{~kg} \mathrm{~N} / \mathrm{ha} / \mathrm{yr}$ for the $0,100,200$ and $400 \mathrm{~kg} \mathrm{~N} / \mathrm{ha} / \mathrm{yr}$ application rates respectively. No differences in these responses were measured between urea and effluent when applied at the same rate of nitrogen. Application of dairy effluent resulted in increased average pasture potassium levels from $3.65 \% \mathrm{DM}$ to $4.00 \% \mathrm{DM}$, which may have implications for animal health. Application of dairy effluent also decreased soil sulphur levels and increased soil magnesium status.
\end{abstract}

Keywords: dairy effluent, groundwater, nitrate leaching, nitrogen, pasture, soil, urea

\section{Introduction}

To decrease point-sources of agricultural pollution into water-ways, most Regional Councils are encouraging land-based effluent disposal systems on dairy farms. Land treatment systems are culturally acceptable, save fertiliser costs for dairy farm effluent users, and meet many Regional Councils' objectives of minimising point sources of ground water and surface water pollution (Selvarajah 1996). However, there is increasing concern over the adverse impact of land-based effluent disposal on non-point source (diffuse) pollution of ground and surface water in dairying areas. Use of nitrogen $(\mathrm{N})$ fertiliser in Taranaki has also increased (Kidd \& Howse 1994). These practices can potentially increase groundwater nitrogen concentrations with possible adverse effects on human and animal health, as well as increasing the loss of nitrogen from the farm system (Selvarajah et al. 1994; Speir \& Kettles 1993; Williamson et al. 1996). In New Zealand, there is little information on environmentally sustainable nitrogen loading rates for dairy farm effluent application onto land (Selvarajah 1996).

A 3-year joint project between the Dairying Research Corporation and the Taranaki Regional Council, with funding from the Ministry for the Environment Sustainable Management Fund, was started in September 1997. The objective of the trial was to identify practical and environmentally sustainable management practices for land-based application of dairy effluent and urea fertiliser. It should be noted that the trial is not yet completed and results presented are from the first 1-2 years of the trial.

\section{Methods and materials}

\section{Treatments}

At the WestpacTrust Agricultural Research Station (WTARS), near Hawera in South Taranaki, urea fertiliser or farm dairy effluent was applied to paddocks at rates of $0,100,200$, or $400 \mathrm{~kg} \mathrm{~N} / \mathrm{ha} / \mathrm{yr}$. Measurements were made of groundwater quality, nitrate leaching, pasture production, pasture composition and quality, and soil fertility.

Three areas (blocks) each consisting of seven, 0.25 ha paddocks were set up and one paddock in each block received one of the following treatments: Nil nitrogen fertiliser (0N); dairy effluent at 100 , 200 , and $400 \mathrm{~kg} \mathrm{~N} / \mathrm{ha} / \mathrm{yr}$ (denoted 100E, 200E and $400 \mathrm{E}$ ); and urea fertiliser at 100,200 , and $400 \mathrm{~kg} \mathrm{~N} /$ ha/yr (denoted 100U, 200U and 400U).

Urea, or effluent from the first (anaerobic) oxidation pond at WTARS, was applied to paddocks monthly, at rates of 25 to $50 \mathrm{~kg}$ N/ha between September and April of each year. Urea was spread using an ATV and spinning disc spreader, and effluent was applied by sprinkler irrigation. Holstein Friesian x Jersey dairy cows grazed the trial area as part of a larger farmlet. At each grazing, cows were divided into four herds (denoted $0 \mathrm{~N}, 100 \mathrm{~N}, 200 \mathrm{~N}$, or $400 \mathrm{~N}$ ) and after 24 hours grazing on a "pre-graze" paddock that had received 
the same rate of nitrogen as urea, the herd grazed all paddocks of the same nitrogen application rate. The "pre-grazing" was to stabilise dung and urine nitrogen concentrations, and prevent transfer of nitrogen between different treatment rates. The number of cows in each herd was determined by the average pasture cover of paddocks grazed by that herd. Each paddock was grazed for 24 hours.

\section{Pasture and soil measurements}

Pasture growth was estimated from weekly visual estimates of pasture cover in each paddock calibrated against twelve, $0.2 \mathrm{~m}^{2}$ quadrats, cut to ground level, washed and dried at $95^{\circ} \mathrm{C}$ for 48 hours. Measured pasture cover was regressed against the visual estimate, and the regression equation used to correct visual estimates. Within each paddock, pasture samples were collected seasonally along fixed transect lines for herbage dissection, and feed quality analysis by nearinfrared reflectance spectroscopy (NIRS). Pasture samples collected in winter and spring were also analysed for nitrogen, phosphorus, potassium, sulphur, calcium and magnesium content by wet chemistry.

In September of each year, soil samples (0-75 mm depth) were collected along a fixed transect within each paddock, and analysed for $\mathrm{pH}$, calcium, phosphorus, potassium, magnesium, sulphate sulphur and organic sulphur by the Soil Fertility Service, Ruakura.

\section{Nitrate leaching and groundwater quality}

Ten ceramic cup samplers installed in each paddock were used to collect samples of soil percolation water at a depth of 1 metre, which were analysed for nitrate-N concentration by Gordon Rajendram, AgResearch. Samples were collected every $40-50 \mathrm{~mm}$ of drainage, resulting in five samplings over each winter. These data, in conjunction with drainage volume measurements from seven lysimeters, were used to estimate nitrogen leaching losses.

Groundwater samples were collected seasonally from 15 monitoring bores, and analysed for $\mathrm{pH}$, electrical conductivity, nitrate, nitrite, potassium, and phosphorus by R.J. Hill Laboratories, Hamilton.

\section{Results}

\section{Pasture}

Annual pasture production in Year 1 is shown in Table 1. Due the small number of replicates (three per treatment), differences were not statistically significant. Pasture production responses to nitrogen application in Year 1 were $10-16 \mathrm{~kg} \mathrm{DM} / \mathrm{kg}$ of nitrogen applied. No differences were observed in responses between nitrogen applied as effluent or as urea, when applied at the same rate of nitrogen. Preliminary results from Year 2 support this trend (data not presented).

Table 1 Annual pasture production in Year 1 (kg DM/ha) from calibrated visual estimates.

\begin{tabular}{lcc}
\hline Treatment & Effluent* $^{\star}$ & Urea \\
\hline $0 \mathrm{~kg} \mathrm{~N}$ & 13520 & 13520 \\
$100 \mathrm{~kg} \mathrm{~N}$ & 14519 & 14678 \\
$200 \mathrm{~kg} \mathrm{~N}$ & 17064 & 16420 \\
$400 \mathrm{~kg} \mathrm{~N}$ & 17246 & 18003 \\
\hline
\end{tabular}

* Within an $\mathrm{N}$ rate and between $\mathrm{N}$ rates, differences were not significant.

The ryegrass content of the pastures increased $(\mathrm{p}<0.05)$ with increasing nitrogen application rates (Figure 1). The content of clover and other grasses tended to decrease with increasing nitrogen application (data not presented). No differences were observed between the pastures under urea and effluent treatments.

Rates or form of nitrogen did not affect the protein, lipid, fibre, energy content, digestibility, nitrogen, phosphorus, sulphur, calcium or magnesium concentration of the pasture grown.

Since winter 1998, pasture potassium content was consistently higher $(\mathrm{P}<0.05)$ under effluent than the $0 \mathrm{~N}$ or urea treatments (Figure 2).

\section{Soils}

Soil potassium $(\mathrm{K})$ levels increased $(\mathrm{P}<0.01)$ in the effluent treated paddocks relative to the $0 \mathrm{~N}$ and urea treatments (Figure 3). Soil sulphate-S levels increased $(\mathrm{P}<0.01)$ under both the urea and $0 \mathrm{~N}$ treatments, but was stable in the effluent treatment (Figure 4). Soil magnesium levels increased under effluent by 12 quicktest units relative to the $0 \mathrm{~N}$ and urea treatments $(\mathrm{P}<0.01)$.

\section{Nitrate leaching and groundwater}

Total nitrogen leaching data for Year 1 (Figure 5) showed that leaching losses in the $0 \mathrm{~N}$ and "100" treatments were similar for the two nitrogen sources. Leaching losses were increased $(\mathrm{P}<0.05)$ in the " 400 " treatments where again, the two nitrogen sources were similar. There was no difference in the amount of nitrate-N leached between effluent and urea when applied at the same rate of nitrogen. Owing to many ceramic cup samplers not working correctly, the data for the "200" treatments are based on a small number of samples, and differences between the $200 \mathrm{U}$ and 200 E treatments were not significant. Preliminary data from Year 2 show similar results to Year 1, and suggests 
Figure 1 The effect of $\mathrm{N}$ application rate on pasture ryegrass content under four $\mathrm{N}$ application rates (there was no significant difference between form of $\mathrm{N}$ when applied at the same rate). Vertical line represents SED.

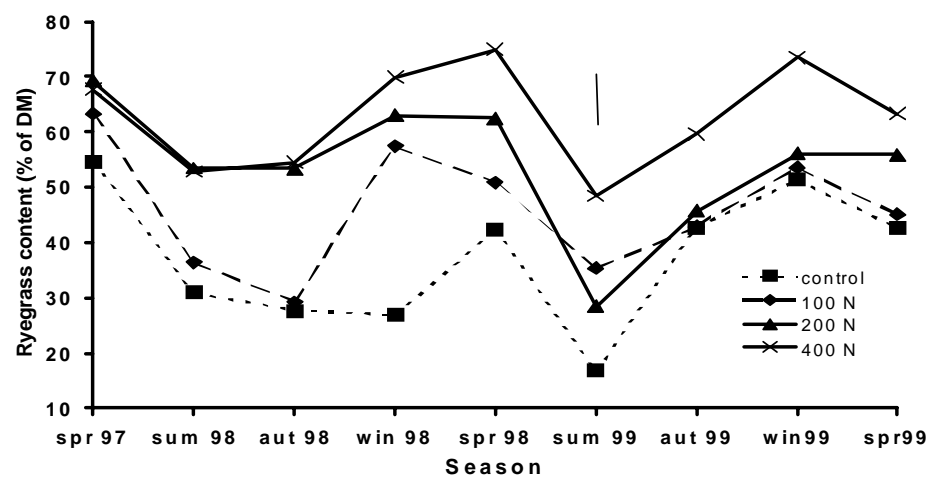

Figure 2 The effect of type of $\mathrm{N}$ fertiliser on pasture potassium (K) content. Vertical line represents SED.

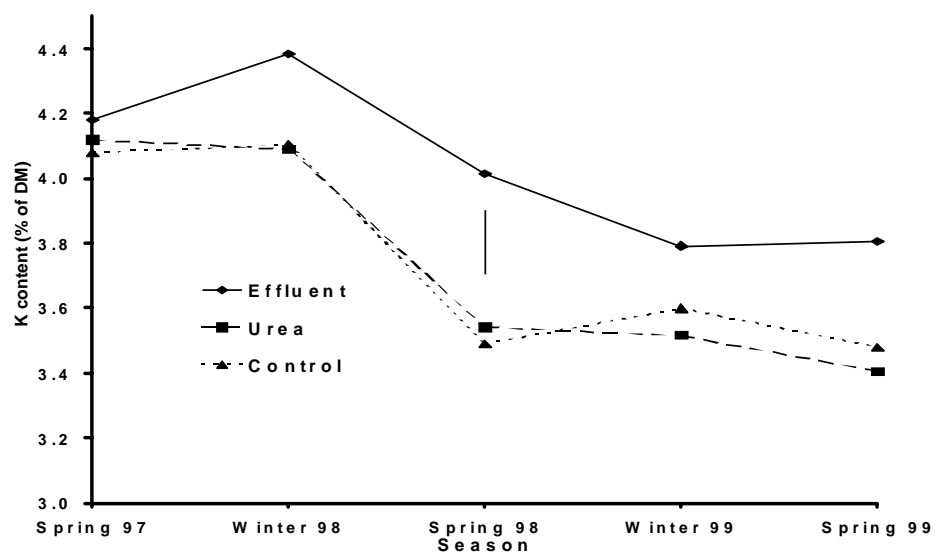

Figure 3 The effect of type of $\mathrm{N}$ fertiliser on soil potassium (K). Vertical line represents SED.

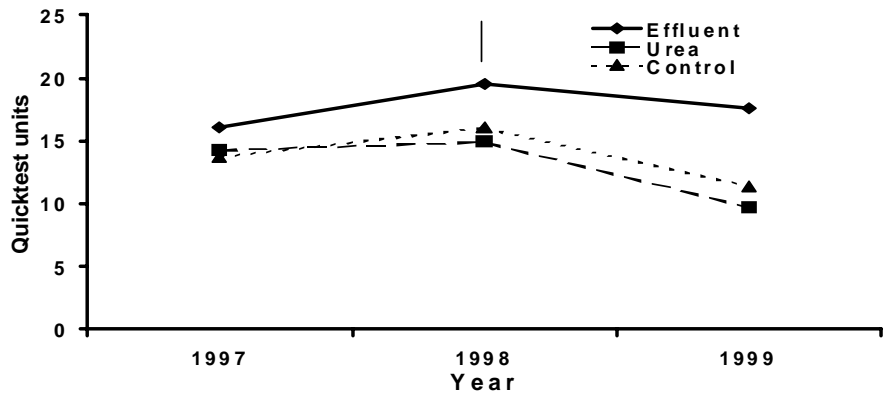

data from Block 1, however, have shown increased groundwater nitrate concentrations under the " 200 " and "400" treatments over both winters (Figure 6). Nitrate concentrations in the groundwater under the $0 \mathrm{~N}$ and " 100 " treatments have remained stable, though levels are generally higher than in the other treatments. Potassium concentrations in groundwater samples have been stable in all but one bore (data not presented).

\section{Discussion}

\section{Nitrogen}

The results of the trial to date suggest that the form of nitrogen fertiliser (urea or dairy effluent) has no effect on pasture production, botanical composition or nitrate leaching. However, the rate of nitrogen application has a large effect on all these factors. Pasture production and botanical composition responses to increasing rates of nitrogen have been consistent with those measured in previous trials. The content of clover tended to decrease with increasing nitrogen application. Increasing fertiliser- $\mathrm{N}$ can reduce clover nitrogen fixation and growth (Harris 1994; Ledgard 1989; Ledgard et al. 1996, 1997).

Nitrate leaching losses were similar for the $0 \mathrm{~N}, 100 \mathrm{E}$ and $100 \mathrm{U}$ treatments, but increased four-fold at $400 \mathrm{~kg} \mathrm{~N} / \mathrm{ha} / \mathrm{yr}$, similar to that measured by Ledgard et al. 1997. This large increase would be expected to have a large impact on groundwater nitrate concentrations. The groundwater nitrate data to date from Block 1 are consistent with the nitrate leaching data. Stable nitrate concentrations were encountered in groundwater below the $0 \mathrm{~N}$ and " 100 " treatments (suggesting low leaching losses) and elevated winter nitrate concentrations were measured below the

leaching losses from the "200" treatments were intermediate between the "100" treatments, and the "400" treatments.

Groundwater samples from replicate Blocks 2 and 3 have shown no consistent treatment effects. The "200" and "400" treatments (suggesting increased leaching losses). The difference in background nitrate concentrations is probably a reflection of the natural variability from paddock to paddock and differences in management of paddocks "upstream" from the bore 
Figure 4 The effect of type of $\mathrm{N}$ fertiliser on soil sulphate-S. Vertical line represents SED.

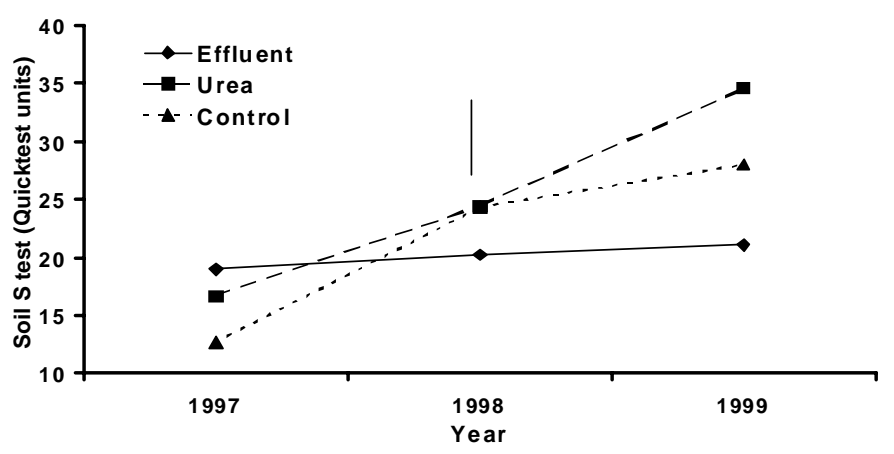

sites. Groundwater nitrate levels under some $0 \mathrm{~N}$ paddocks were already above recommended levels (11.3 grams/cubic metre) for drinking water. This variability and the potential uses of the groundwater are important in determining what level of nitrate leaching is sustainable. As Block 1 has the shallowest groundwater reserves of the three blocks, it might be expected that similar differences in groundwater nitrate will occur in the other blocks in the future. Groundwater occurs up to 6.5 metres below ground level at these sites, and it may take several years before the large amounts of nitrate

Table 2 The amounts of other nutrients $(\mathrm{kg} / \mathrm{ha})$ applied in effluent in Year 2, compared with maintenance requirements (kg/ha/yr).

\begin{tabular}{lccc}
\hline Treatment & Potassium & Phosphorus & Sulphur \\
\hline $100 \mathrm{~kg} \mathrm{~N}$ & 72 & 11 & 10 \\
$200 \mathrm{~kg} \mathrm{~N}$ & 126 & 19 & 13 \\
$400 \mathrm{~kg} \mathrm{~N}$ & 264 & 38 & 26 \\
Maintenance & 60 & 45 & 30 \\
\hline
\end{tabular}

measured leaching from the " 400 " treatments have an effect on the groundwater. In a similar Waikato trial (Ledgard et al. 1996), groundwater differences at 3 metre depths were not observed until near the end of the second year.

The effluent application rates approximately equate to applying effluent each year to 10,5 , and $2.5 \%$ of the farm for the $100 \mathrm{E}, 200 \mathrm{E}$ and $400 \mathrm{E}$ treatments respectively, assuming a stocking rate of 2.5 cows/ha.
Figure 5 The effect of $\mathrm{N}$ application rate and fertiliser type on total nitrogen leaching in Year 1.

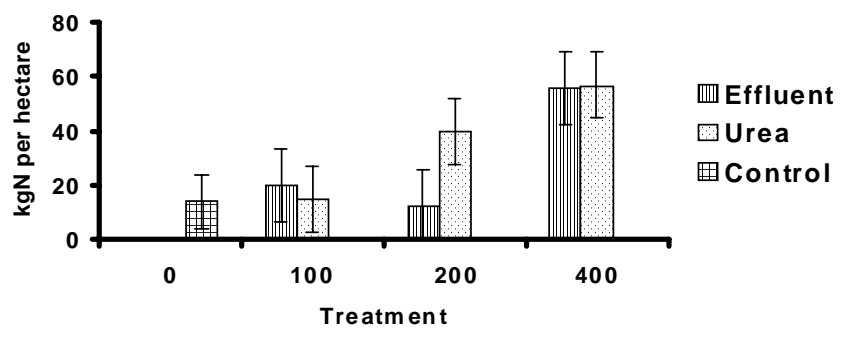

Figure 6 The effect of $\mathrm{N}$ application rate on nitrate nitrogen concentration in groundwater in Block 1. Each point is from one sample only.

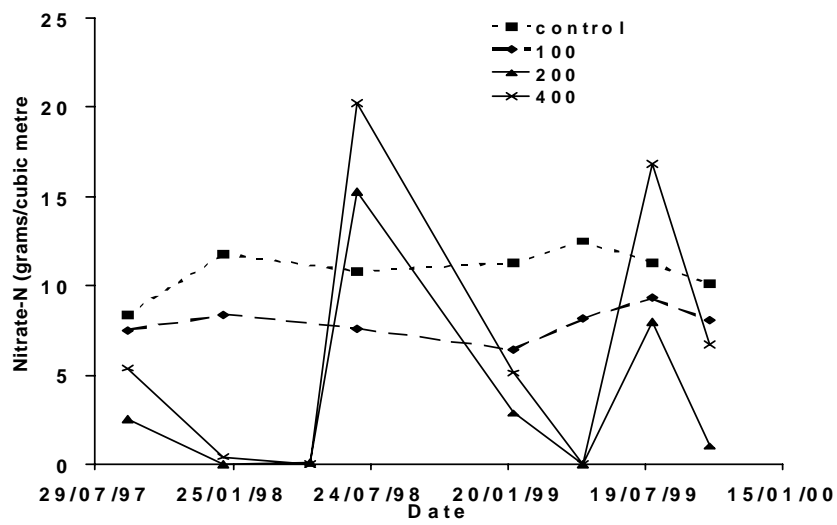

\section{Other nutrients}

Effluent application applied more potassium than recommended (Roberts \& Edmeades 1993) for maintenance at each application rate (Table 2). However, phosphorus and sulphur supplied in the effluent was below recommended maintenance applications. In addition, $45 \mathrm{~kg} / \mathrm{ha}$ of phosphate $(\mathrm{P})$ and $60 \mathrm{~kg} /$ ha of potassium $(\mathrm{K})$ and sulphur $(\mathrm{S})$ were applied annually to all paddocks as potassic superphosphate. The amount of effluent nitrogen produced on a dairy farm was calculated (using measured nutrient concentrations and estimated effluent volumes) to be approximately $5 \mathrm{~kg} \mathrm{~N} / \mathrm{cow} /$ year. The fertiliser value of the major nutrients $(\mathrm{N}, \mathrm{P}$, $\mathrm{K}$, and $\mathrm{S}$ ) was calculated at $\$ 8-\$ 10 /$ cow/year using current fertiliser prices.

Increased pasture and soil potassium levels were largely owing to the quantities of potassium applied in the effluent. The increase in pasture potassium levels has important implications for animal health, with high pasture potassium levels affecting calcium and magnesium metabolism in dairy cows, which can lead to milk fever and grass staggers. By using low application rates and not applying potassium fertilisers to areas where effluent is spread, potential problems 
could be avoided. Applying effluent at $100 \mathrm{~kg} \mathrm{~N} / \mathrm{ha} / \mathrm{yr}$ supplies approximately maintenance levels of potassium, and also minimises nitrate leaching. Potassium concentrations in groundwater samples have been stable in all but one bore, which is located near the effluent ponds and may be affected by seepage from the ponds. This is despite the large amounts of potassium applied in the effluent. An associated trial has measured no significant difference in potassium leaching between $\mathrm{N}$ treatments (S.F. Ledgard, pers. comm.). Potassium leaching and effects on groundwater may occur in the future.

The increase in soil sulphate-S under the urea and control treatments in 1999 was expected owing to annual fertiliser $\mathrm{S}$ applications being above maintenance sulphur requirements. It was expected that soil sulphur would have increased at a similar rate under the effluent treatment, since the areas received the same fertiliser applications, and additional sulphur was applied in the effluent. The lack of response to extra sulphur may be owing to an interaction with, or displacement by, another component of the effluent. Soils at this site are sulphur retentive, and associated work has measured no difference in sulphate leaching between effluent and urea treatments (S.F. Ledgard \& G.S. Rajendram, pers. comm.), suggesting some sulphur has moved further down the soil profile in the effluent treatments. Deeper soil sampling will provide data to test this theory.

\section{Conclusions}

These preliminary results suggest:

- Increasing nitrogen application rates increased pasture production, ryegrass content and nitrate leaching.

- One kilogram of nitrogen from effluent was equivalent to one kilogram of nitrogen from urea, in terms of pasture production, composition and nitrate leaching.

- Nitrate leaching was similar at 0 and $100 \mathrm{~kg} \mathrm{~N} / \mathrm{ha}$ and greatly increased at $400 \mathrm{~kg} \mathrm{~N} / \mathrm{ha}$.

- Nitrate leached from the pasture root zone may take several years to affect groundwater quality.

- Background groundwater nitrate concentrations can vary greatly across sites.

- Other nutrients in effluent, particularly potassium, affect pasture and soil.

- Low effluent application rates (less than $400 \mathrm{~kg} \mathrm{~N} /$ ha/yr) are advisable to minimise nitrate leaching and animal health effects.

\section{ACKNOWLEDGEMENTS}

Taranaki Regional Council for funding and technical assistance. Ministry for the Environment for funding assistance. Rachel Barton, Kendra Davis, Brian Walsh, Claire Cooper, Steve Blakely, Kelly Andrews and Lynette Maulder at the WestpacTrust Agricultural Research Station for assistance conducting the trial. Stewart Ledgard, Mike Sprosen and Gordon Rajendram at AgResearch for technical assistance and advice.

\section{REFERENCES}

Harris, S.L. 1994. Nitrogen and white clover. Proceedings of the Ruakura Farmers' Conference 46: 22-28.

Kidd, Y.; Howse, S. 1994. Farmers attitudes to nitrogen fertilisers. Proceedings of the Ruakura Farmers' Conference 46: 29-35.

Ledgard, S.F. 1989. Nitrogen fixation by pasture legumes as influenced by soil or fertilizer nitrogen. pp. 131-138. In: Nitrogen in New Zealand Agriculture and Horticulture. Eds: White R.E. ; Currie L.D. Occasional Report No. 3, Fertilizer and Lime Research Centre, Massey University, Palmerston North, New Zealand.

Ledgard, S.F.; Clark, D.A.; Sprosen, M.S.; Brier, G.J.; Nemaia, E.K.K. 1996. Nitrogen losses from grazed dairy pasture, as affected by nitrogen fertiliser application. Proceedings of the New Zealand Grassland Association 57: 21-25.

Ledgard, S.F.; Penno, J.W.; Sprosen, M.S. 1997. Nitrogen balances and losses on intensive dairy farms. Proceedings of the New Zealand Grassland Association 59: 49-53.

Roberts, A.H.C.; Edmeades, D.C. 1993. Fertiliser Use on Dairy Farms. Dairying Research Corporation Ltd, Hamilton, New Zealand.

Selvarajah, N. 1996. Determination of sustainable nitrogen loading rates for land treatment systems without adequate soil and ground water information: dairy farm effluent application onto grazed pasture in the Waikato region. pp. 85-103. In: Recent Developments in Understanding Chemical Movements in Soils: Significance in Relation to Water Quality and Efficiency of Fertiliser Use. Eds: Currie, L.D.; Loganathan, P. Occasional Report No. 9. Fertilizer and Lime Research Centre, Massey University, Palmerston North, New Zealand.

Selvarajah, N.; Maggs, G.R.; Crush, J.R.; Ledgard, S.F. 1994. Nitrate in Ground Water in the Waikato Region. pp. 160-185. In: The Efficient Use of Fertilizers in a Changing Environment: Reconciling Productivity and Sustainability. Eds: Currie, L.D.; Loganathan, P. Occasional Report No. 7, Fertilizer and Lime Research Centre, Massey University, Palmerston North.

Speir, T.W.; Kettles, H.A. 1993. The Potential Role of Nitrification Inhibitors to Reduce Nitrogen Losses 
from Land-Treated Farm Wastes. Land Application of Farm Wastes: Technical Session 9. New Zealand Land Treatment Collective October 1993, Christchurch, New Zealand.

Williamson, J.C.; Menneer, J.C.; Torrens, R.S. 1996. Impact of Dicyandiamide on the Internal Nitrogen Cycle of a Volcanic Silt Loam Soil Receiving Effluent. Applied Soil Ecology 4: 39-48. 